\author{
Andrzej J. Sowiński* \\ Gorzów Wielkopolski
}

\title{
Dziecko jako osoba i inspiracja samowychowania rodziców
}

\author{
Jeśli się nie staniecie jako dzieci, \\ nie wnijdziecie do Królestwa niebieskiego
}

(Mt 18, 3)

Artykuł opatrzony został mottem wyjętym z Ewangelii. Słowa te mają swoje wyjaśnienie na gruncie teologii. Natomiast pedagogów i rodziców jako naturalnych wychowawców dziecka słowa te powinny zachęcać do namysłu w celu zrozumienia, czym jest dar dziecka, jaka jest istota i natura dzieciństwa oraz jak pielęgnować wrodzoną zdolność dziecka do rozwoju.

Poniższy tekst stanowi pewnego rodzaju refleksję nad Listem do Rodzin Ojca Świętego Jana Pawła II, który został napisany w roku $1994^{1}$ z okazji obchodzonego przez Kościół Roku Rodziny. Nie jest to jednak refleksja filozoficzna czy filologiczna, ani też teologiczna. Ten szczególny List można oczywiście przeczytać jak każdy inny, z mniejszą lub większą uwagą i zrozumieniem, jednakże w tym przypadku zamierzeniem ponownego odczytania Listu jest wydobycie i ukazanie jego pedagogicznego sensu. List otwiera bowiem możliwości poszukiwania dalszych implikacji i interpretacji zawartych w nim treści, którym autor poniższych rozważań pragnie nadać wyraz

* Dr hab. Andrzej J. Sowiński jest wykładowcą w Państwowej Wyższej Szkole Zawodowej im. Jakuba z Paradyża w Gorzowie Wielkopolskim.

${ }^{1}$ List do Rodzin Ojca Świętego Jana Pawła II, Szczecin 1994 - w tekście cytowany poprzez skrót LdR z odnośnym numerem. 
dociekań i wynikających stąd pewnych propozycji o charakterze pedagogicznym.

\section{Rodzina chrześcijańska}

List Jana Pawła II skierowany jest „do konkretnych rodzin na całym globie", żyjących pod każdą długością i szerokością geograficzna, pośród całej wielości kultur oraz ich dziedzictwa historycznego (LdR 4). Jednak uwagi poczynione w niniejszym tekście dotyczą rodzin w Polsce.

Dla pedagoga wyjściową konstatacją w podjętym namyśle jest teza mówiąca o tym, że rodzina tworzy naturalne środowisko wychowania, co wyróżnia ją w sposób jednoznaczny wśród innych środowisk, grup czy instytucji społecznych. „Wychowanie chrześcijańskie opiera się na założeniach religii chrześcijańskiej, której ideałem jest miłość Boga i bliźniego. W tej religii Bóg pojmowany jest personalistycznie i w zasadzie On jest głównym wychowawcą"2. Co więcej, najbardziej charakterystyczną cechą każdego środowiska wychowawczego jest jego sfera aksjologiczna. Odnosząc to do rodziny chrześcijańskiej, można zauważyć, że wśród immanentnych cech właśnie wartości chrześcijańskie i sposób ich realizacji definiują jej religijną genezę i przynależność do Kościoła, rozumianego teologicznie i socjologicznie. Kościół bowiem spełnia swoją misję i pragnie partycypować w wychowaniu chrześcijańskim, czyniąc to jednak ,poprzez rodzinę, w oparciu o jej taskę stanu i charyzmat wspólnoty rodzinnej” (LdR 16). Swoistość rodziny chrześcijańskiej wraża się we wzajemnej miłości między rodzicami i dziećmi, będącej fundamentalną zasadą życia małżeńskiego i rodzinnego. Od strony psychologicznej miłość stanowi potrzebę psychiczną człowieka niezbywalną, ponieważ bez możliwości jej zaspokojenia człowiek jako osoba nie potrafi żyć. Właściwością tej potrzeby jest to, że polega ona na obdarzaniu dobrem innych i przyjmowaniu dobra od innych osób. Można więc przyjąć, że miłość jest z jednej strony dobrowolnym, szczodrym i bezinteresownym obdarowywaniem posiadanymi własnościami osobowymi i rzeczowymi innych osób, grup i zbiorowości w celu ich rozwinięcia, doskonalenia i wzbogacenia, z drugiej zaś, jest wdzięcznym przyjmowaniem od nich wszelkiego dobra, które mogą nam przekazać. „To miłość właśnie sprawia, że człowiek urzeczywistnia siebie przez bezinteresowny dar z siebie. Miłość bowiem jest dawaniem i przyjmowaniem daru. Nie można jej kupować ani sprzedawać.

2 R. Jusiak, Pedagogia społeczna Kościoła Katolickiego, Lublin 2013, s. 90. 
Można się nią tylko wzajemnie obdarowywać" (LdR 11). Prawda ta odnosi się także do wychowania w rodzinie, którego fundamentem jest miłość.

Inną cechą rodziny chrześcijańskiej, równie ważną jak miłość, a może tylko jej konsekwencją jest rodzicielstwo, a więc macierzyństwo i ojcostwo. Rodzina i rodzicielstwo są z sobą ściśle związane. „Są to poniekąd słowa kluczowe" (LdR 23) do zrozumienia istoty posłannictwa rodziny oraz roli, jaką spełnia w nim wychowanie. Wychowanie w kontekście rodzicielstwa definiuje ks. J. Tischner w następującym ujęciu filozoficznym: „Wychowanie to praca z człowiekiem i nad człowiekiem - z tym, kto znajduje się w stanie dojrzewania. Wychowanie stwarza między wychowawcą a wychowankiem więź, analogiczną do więzi ojcostwa. Ojcostwo to nie tylko przekazywanie życia, ojcostwo to również przekazywanie nadziei. Praca wychowawcy jest przede wszystkim pracą nad nadzieją człowieka"3. I tu powracamy do warstwy aksjologicznej rodziny chrześcijańskiej, bo nadzieja jako wartość zawarta jest kulturze chrześcijańskiej, stąd wychowanie w rodzinie można postrzegać również jako przekaz dziedzictwa kulturowego i religijnego.

Wśród innych cech rodziny chrześcijańskiej niektórzy pedagodzy podkreślają jeszcze jeden istotny walor, wspólny rodzinom w ogóle i doniosły z punktu widzenia naszych rozważań ${ }^{4}$. Otóż, rodzina stanowi naturalne środowisko wychowania. Kwestia ta wymaga jednak pewnej interpretacji, polemicznej w stosunku do sensu, jaki powszechnie nadaje się temu określeniu. Po pierwsze, należy odróżnić naturalność środowiska od naturalności wychowania. Naturalność środowiska może być rozumiana dwojako5: jako samoistny sposób powstania środowiska społecznego na podłożu wrodzonych, ludzkich dążeń, potrzeb czy zainteresowań (tak powstaje rodzina i grupa rówieśnicza $)^{6}$ lub/i jako przynależna środowisku właściwość immanentna, objawiająca się między innymi spontanicznym, niezamierzonym wywieraniem wpływu na osobowość jednostek, poprzez ich uczestnictwo w codziennych sytuacjach życiowych ${ }^{7}$. Natomiast naturalność wychowania oznacza, że jest

${ }^{3}$ J. Tischner, Etyka Solidarności, Warszawa 1981, s. 75.

${ }^{4}$ A. J. Sowiński, Szkice do teorii wychowania kreatywnego, Kraków 2013, s. 20.

${ }_{5}^{5}$ Celowo pomijam tutaj pojęcie środowiska naturalnego, wynikające z typologii opartej na rodzaju bodźców środowiskowych, które Ryszard Wroczyński definiuje jako układ geofizyczny, będący dziełem samej natury, a jego elementy nie wymagają interwencji człowieka. R. Wroczyński, Pedagogika społeczna, Warszawa 1976, s. 78-79.

${ }^{6}$ Por. F. Adamski, Socjologia matżeństwa i rodziny. Wprowadzenie, Warszawa 1982, s. $21-27$.

7 Por. A. Kamiński, Funkcje pedagogiki społecznej, Warszawa 1974, s. 45. Należy przy tym zauważyć, że właściwie każdy rodzaj ludzkiej działalności, niezależnie od jej ukierun- 
to działalność podejmowana w sposób intencjonalny, mniej lub bardziej planowy i refleksyjny (często intuicyjny), przebiegająca w środowisku naturalnym, w codziennych (a więc naturalnych) sytuacjach życia. Alternatywą wychowania naturalnego jest wychowanie profesjonalne, organizowane w środowiskach społecznych (szkoła, instytucje edukacyjne pozaszkolne i inne) specjalnie powołanych dla realizacji celów i zadań wychowawczych. Łącząc te dwa wyróżnione człony, to jest naturalność środowiska z naturalnością wychowania, otrzymujemy zbitkę pojęciową, jaką jest naturalne środowisko wychowania ${ }^{8}$. Jak z tego wynika, naturalność nie niweczy intencjonalności. O doniosłej w biografii człowieka roli rodziny, która stanowi naturalne środowisko wychowania, trzeba nieustannie przekonywać całe społeczeństwo, gdyż to właśnie rodzina, a nie żłobek ${ }^{9}$, przedszkole i szkoła, jest pierwszym i niezastappionym źródłem przekazu symbolicznego oraz doświadczeń kształtujących w dziecku człowieczeństwo.

Pojawienie się w rodzinie dziecka (i kolejnych dzieci) staje się sytuacją inspirującą rodziców do organizowania własnego życia rodzinnego. Najogólniej dzieje się to na dwu możliwych drogach: w pierwszym przypadku rodzice odwzorowują lepsze przykłady (wzorce) funkcjonujące w środowisku, w drugim tworzą życie rodzinne według własnego pomysłu. Nie zmienia to w niczym ogólnej zasady, że dziecko wyzwala w rodzicach energie, akty miłości i dobroci materializujące się w jakości życia rodzinnego, a także, co nie zawsze jest dostrzegane, wyrażające się w kumulowaniu lub rozwijaniu dobra w sobie. I ten kapitał dobra i mądrości bywa czynnikiem motywującym rodziców do doskonalenia siebie samych. Jednak jest to zawsze jedynie pewna sprzyjająca okoliczność, możliwość, nigdy zaś konieczność.

kowania i charakteru (np. działalność gospodarcza, sportowa, artystyczna, zabawowa itp.), podejmowanej w sytuacjach życiowych/społecznych określonego środowiska, może mieć wpływ osobotwórczy (inaczej: socjalizacyjny).

${ }^{8}$ Profesjonalne wychowanie może być podejmowane także w rodzinie. Tak było w dawnej Polsce, kiedy to w zamożnych domach zatrudniano guwernantkę, to jest osobę pełniącą rolę nauczycielki domowej i wychowawczyni dzieci. Odwrotna sytuacja występuje wówczas, kiedy to w instytucjach edukacyjnych (np. w szkole, organizacji młodzieżowej) dąży się do tego, aby wychowanie profesjonalne upodobnić do wychowania naturalnego.

${ }^{9}$ W jednej z wrześniowych (w 2008 roku) dyskusji telewizyjnych była minister edukacji, pani Łybacka, posłanka SLD, domagała się upowszechnienia w Polsce instytucji żłobków (inicjatywy antywychowawczej i skompromitowanej), zakładanych w czasach PRL-u przy większych zakładach pracy. 


\section{Wychowanie w rodzinie chrześcijańskiej}

Kwestią decydującą o ogólnym charakterze wychowania w rodzinie chrześcijańskiej, w odróżnieniu od wychowania w rodzinie na przykład muzułmańskiej czy ateistycznej i innej, jest jego ujęcie w perspektywie personalistycznej. Zatem chcąc dociec istoty tego wychowania, warto prześledzić schemat procesu wychowania w relacjach osobowych. Najprostszy schemat takiego procesu złożony jest z trzech elementów: rodzica, dziecka oraz interakcji wychowawczych zachodzących między tymi osobami. Nie ulega żadnej wątpliwości, że podmiotem wychowania jest rodzic będący wychowawca. „Są wychowawcami, ponieważ są rodzicami” (LdR 16). Dziecko jako osoba jest również nie tyle podmiotem (autentycznym) wychowania, ile podmiotem własnych działań i zachowań przejawianych w naturalnych sytuacjach życia rodzinnego, które jednakże pozostają pod kontrolą rodziców oraz w dużej części są przez nich tworzone i organizowane, i co ważne, ze świadomością ich wychowawczego wpływu. W całej konstrukcji procesu istotną rolę spełniają interakcje, które nadają praktycznym działaniom rodziców sens wychowawczy. To, na czym polega doniosłość owych interakcji, podaje w swojej definicji wychowania Klaus Scheller: „Wychowanie to całokształt sposobów i procesów pomagających istocie ludzkiej - zwłaszcza przez interakcje - urzeczywistniać swoje człowieczeństwo". Końcowy efekt interakcji od strony teologicznej jeszcze wyraźniej ukazuje i wyjaśnia Autor Listu, pisząc o Boskiej pedagogii w sposób następujący: „W tym szczytowym punkcie naszego Odkupienia [w tajemnicy śmierci i zmartwychwstania Chrystusa - przyp. A. S.] rozpoczyna się cały i każdy proces chrześcijańskiego wychowania, które jest zarazem wychowaniem do pełni człowieczeństwa" (LdR 16). To w Boskiej pedagogii oznacza zaś, że pełnym wymiarem człowieczeństwa jest synostwo Boże.

Wracając do interakcji, należy zauważyć, że mają one zawsze kierunek dwustronny: osoba A wysyła sygnały (np. słowne, mimiczne), które odbiera osoba B. Osoba B czyni to samo w stosunku do osoby A. Tak więc każda z tych osób jest jednocześnie nadawcą i odbiorą pewnych sygnałów. Sygnały odebrane muszą być jednak zrozumiałe, ponieważ tylko wówczas zachodzi między tymi osobami komunikacja. I wreszcie powinien być spełniony trzeci warunek pełnej interakcji: osoba $\mathrm{A} w$ ten sposób oddziałuje na osobę $\mathrm{B}$, a także osoba B wpływa na zachowania osoby A. W przypadku interakcji wychowawczych rodzice wywołują, zmieniają lub wzmacniają pożądane zachowania dziecka, kształtując jego psychikę i duchowość. Również dziecko 
jako osoba posiadająca własną podmiotowość wpływa na zachowania swoich rodziców. Na tę obustronną i wzajemną właściwość procesu wychowania zwraca szczególną uwagę Autor Listu: „Wychowanie jest więc przede wszystkim obdarzaniem człowieczeństwem - obdarzaniem dwustronnym. Rodzice obdarzają swym dojrzałym człowieczeństwem nowonarodzonego człowieka, a ten z kolei obdarza ich całą nowością i świeżością człowieczeństwa, które z sobą przynosi na świat" (LdR 16). Nie oznacza to jednak, że dziecko staje się wychowawcą swoich rodziców, lecz oznacza jedynie to, że dziecko może stać się źródłem inspiracji do samowychowania rodziców.

\section{Samowychowanie rodziców}

Rodzice chrześcijańscy zdają sobie dobrze sprawę z tego faktu, że nie są wychowawcami doskonałymi, ponieważ nie są w stanie zaspokoić wszystkich potrzeb integralnego rozwoju dziecka, a sam proces wychowania z natury rzeczy wymaga wsparcia i profesjonalnej pomocy instytucji społecznych i państwa (przedszkola, szkoły i innych). Wielką pomoc w dziedzinie wychowania religijno-moralnego dziecka, a także we własnym samodoskonaleniu, otrzymują rodzice ze strony Kościoła. Kościół spełnia w ten sposób swoją misję i pragnie partycypować w wychowaniu, czyniąc to jednak ,poprzez rodzinę, w oparciu o jej łaskę stanu i charyzmat wspólnoty rodzinnej” (LdR 16).

W wielu przypadkach rodzice chcą towarzyszyć dziecku nie tylko w pierwszym okresie dziecięctwa, w którym dominują czynności opiekuńcze, ale także w dalszych etapach jego rozwoju, kiedy fundamentalnego znaczenia nabiera wychowanie. „Proces wychowawczy prowadzi do fazy, do której się dochodzi wtedy, gdy po osiagnięciu pewnego stopnia dojrzałości psychofizycznej człowiek zaczyna wychowywać się sam" (LdR 16). Jednakże wychowanie dziecka do samowychowania jest zadaniem bardzo trudnym, potrzebna jest $\mathrm{w}$ tym zakresie wiedza i własne doświadczenie. Pisała o tym w sposób metodyczny z ilustracją doskonałych przykładów T. Kukołowicz w swojej książce Pomagamy w samowychowaniu ${ }^{10}$.

Obok wymienionych okoliczności i motywacji prowadzących do podejmowania przez rodziców samodoskonalenia, czy to z pobudek religijnych wynikających z uczestnictwa w życiu Kościoła, czy z wcześniejszych do-

10 Zob. T. Kukołowicz, Pomagamy w samowychowaniu, Warszawa 1984. 
świadczeń zaprawiających do pracy nad sobą, znajdują oni zawsze wspaniałą inspirację do własnego samowychowania w osobie przychodzącego na świat dziecka. I właśnie na tym polega znaczenie osobotwórczych relacji, nawiązywanych przez rodzica z dzieckiem, że są one obustronne i w jakimś sensie symetryczne. Rozwój dziecka może stać się czynnikiem samodoskonalenia rodziców, jeśli zechcą oni walory tego rozwoju w pełni dostrzec i podjąć refleksję, nie tyle nad samym dzieckiem, ile nad własną osobą w kontekście swoistości rozwojowych dziecka.

Przyjście dziecka na świat i radość ciagłego z nim obcowania stwarzają wiele okazji do refleksji nad sensem ludzkiego życia, nad własnym powołaniem. Rodzice mogą stawiać sobie pytania typu: kim jestem? Jakie jest moje zadanie na Ziemi? Jaka powinna być dobra matka/ojciec? A zaraz po nich przychodzi namysł nad sobą: jaka/jaki jestem? Co muszę w sobie zmienić, aby dobrze wypełnić obowiązki matki/ojca? Dziecko jakby na nowo wywołuje u rodziców doznania afirmujące wartość życia, jego naturę i piękno, prowokuje do zadumy nad godnością osoby, nad wielorakimi jej potrzebami, nie tylko cielesnymi. Owe myśli i uczucia mogą stanowić mocną podstawę dla aspiracji perfekcjonistycznych. Te zaś pociągają za sobą chęć ich realizacji poprzez planowanie działań w stosunku do własnej osoby, jednak ciagle w kontekście wyzwań, jakie tworzy dynamika rozwoju dziecka. Zaktualizowane $\mathrm{w}$ ten sposób energie i napięcia psychiczne mogą być pożytecznie rozładowane $\mathrm{w}$ wielorakich działaniach samowychowawczych, na przykład w pokonywaniu własnych słabości, złych przyzwyczajeń, lenistwa, w zdobywaniu umiejętności lepszej organizacji dnia zwykłego i świątecznego, w samodyscyplinie w zakresie korzystania $\mathrm{z}$ telewizji, telefonu, itp. Nie sposób ukazać bogactwa możliwych czynności samodoskonalących, ich mocno zindywidualizowanej różnorodności i wymogów wzrastającego poziomu wykonawczego.

Okazji do podjęcia przez rodziców pracy nad sobą z przyczyny jakby nieplanowanej, jednak stymulującej za sprawą dziecka, jest znacznie więcej. Warto zatrzymać się przynajmniej na dwu ważnych okolicznościach. Pierwsza dotyczy sytuacji, gdy dziecko poznaje świat. W procesie tym, trwającym od momentu urodzenia dziecka przez długi okres dzieciństwa, a czasem dłużej, uczestniczą rodzice. Okoliczność ta niejednokrotnie zmusza rodziców do głębszego zrozumienia zjawisk, które do tej pory były dla nich oczywiste, czasem pomijane lub zupełnie nieznane. Niezależnie od starań szkoły i nauczycieli, również rodzice, jeśli pragną towarzyszyć dziecku w jego procesie poznawczym, mogą uzupełniać wiedzą swoją niewiedzę i pogłębiać rozumienie wiedzy już wcześniej zdobytej. Jest to także dobry pretekst do 
retrospektywnego spojrzenia na sam sposób zdobywania wiedzy, na rewizję własnych porażek, błędów i niekonsekwencji myślenia, itp.

Druga okazja, której rodzice najczęściej nie doceniają, związana jest z rozwojem moralnym dziecka. Rodzice mają możliwość obserwowania zachowań spontanicznych i naturalnych swojego dziecka, które przejawiane są w wielu sytuacjach rodzinnych, prac domowych, zabawowych, w czasie spełnianych obowiązków, w chwilach przeżywanych prywatnie lub społecznie. $\mathrm{W}$ procesie wychowania rodzice nadaja tym sytuacjom i zachowaniom wymiar moralny. Czynią to chociażby przez formułowaną ocenę (na przykład chwaląc dziecko, gdy jest grzeczne, dobre lub aprobując jego prawdomówność, dzielność czy bezinteresowność zachowań). I tu pojawia się wspaniała okazja do rewizji własnych zachowań i własnej indywidualnej moralności, być może obudzi się w tym momencie pragnienie rozwoju estetycznego albo bardziej aktywnego uczestnictwa w kulturze, a może ujawni się także potrzeba pogłębienia życia duchowego.

\section{Kierowanie samowychowaniem dziecka}

Jedną z charakterystycznych cech uprawianego przez rodziców samowychowania jest jego dynamiczność. Praca nad sobą podjęta z inspiracji pojawienia się w rodzinie dziecka, którego osoba wypełnia swoją obecnością życie rodziców i nadaje sens spełnianym wobec niej powinnościom rodzicielskim, zmienia się wraz z upływem czasu, rozszerza się jej zakres i pogłębia efektywność. Źródłem owej dynamiczności jest z jednej strony indywidualny rozwój podmiotu inspiracji, z drugiej zaś cykliczność procesu samowychowania. Fenomen samowychowania, będący w istocie procesem intrapersonalnym, tworzą pewne etapy przeżyć i doświadczeń, których zaistnienie jeszcze nie kończy całego procesu, lecz przeciwnie, wzbudza motywację do ponowienia jego cyklu, z tym jednak, że odbywa się to już na wyższym poziomie świadomości i realizacji. Pełną strukturę procesu samowychowania tworzą następujące etapy: a) idealizacja, która polega na przyswojeniu sobie i zaakceptowaniu jakiegoś moralnie uzasadnionego ideału lub wzoru osobowego; b) samopoznanie, będące uświadomieniem obrazu własnej osoby pod jakimś względem; c) samoocena, która jest przeżyciem własnej oceny płynącej z porównania siebie z przyjętym ideałem lub wzorem; d) aspiracje perfekcjonistyczne motywujące do czynności, których celem jest dokonanie określonych zmian w sobie; e) decyzje samorealizacyjne ustalające program własnego postępowania; f) działania samowychowawcze 
w postaci podejmowania wobec siebie określonych decyzji, prób, ćwiczeń, zadań, itp.; g) samokontrola polegająca na porównaniu i ocenie uzyskanych rezultatów pracy nad sobą z zamierzeniami. Jak łatwo zauważyć, uruchomiony proces samowychowania za sprawą owej cykliczności posiada naturalną tendencję do oderwania się od podmiotu swojej inspiracji. Niebezpieczeństwo takiego quasi ,porzucenia” osoby dziecka, pozostawienia go z niezaspokojoną potrzebą samorealizacji, a zajęcie się rozwojem własnej osoby jest zawsze realne. Częściej jednak mamy do czynienia z zanikiem u rodziców zainteresowania samowychowaniem lub przerwaniem na jakimś poziomie pracy nad sobą. Na szczęście pomoc przychodzi od strony podmiotu inspiracji samowychowawczej, który nie tylko żyje i jest osobowo obecny, lecz podlega rozwojowi w różnych sferach swojej osoby i również pragnie się doskonalić. Fakt ten niejako zmusza rodziców do przeorientowania dotychczasowej organizacji wychowania w kierunku kierowania samowychowaniem wzrastającej i dojrzewającej córki lub syna, co pociaga za sobą konieczność pogłębienia własnej pracy rodziców nad sobą, w pewnym stopniu adekwatnej do nowej sytuacji psychospołecznej, moralnej i duchowej, w jakiej znajduje się ich dziecko. Kierowanie samowychowaniem jest niewątpliwie zadaniem bardzo złożonym i trudnym. Tu już nie wystarcza samo zachęcanie do pracy nad sobą, ale także nie można wyręczać dziecka w samowychowaniu i wkraczać w jego intymny świat. Pozostaje zatem jedyna możliwość wynikająca z respektowania zasady, wedle której nie sposób pomóc komuś w jego indywidualnym trudzie nad własnym rozwojem, nie praktykując samemu i nie posiadając osobistych doświadczeń w uprawianiu samowychowania, którymi można się dzielić z innymi.

Bywa, że zasada ta skłania rodziców do zaangażowania się, czasem razem z dorastającym dzieckiem, w społeczne formy aktywności samowychowawczej. Kształt życia społecznego, jego kulturowe uwarunkowania, a także własne wybory oraz doświadczenie nabyte we wcześniejszych okresach życia, przesądzają o tym, czy rodzice będą kontynuować trud pracy nad sobą, czy też uznają ten obszar aktywności za mało ważny w obliczu innych zadań lub trosk codzienności. Jeśli nastąpi kontynuacja, to wówczas taka ewentualność otworzyć może nowe perspektywy twórczej aktywności samowychowawczej, związanej na przykład z rozwijaniem własnych zamiłowań i zainteresowań w ramach funkcjonujących w środowisku lokalnym stowarzyszeń, instytucji no-profit, zespołów amatorskich czy innych grup aktywnego uczestnictwa w kulturze (towarzyskich, wolontariackich, religijnych i innych). Zamiłowania i zainteresowania wyrażają poznawczo-emocjonalne nastawienie człowieka do rzeczywistości i przybierają postać ukierunkowa- 
nej aktywności, która posiada własną dynamikę ${ }^{11}$. Rodzice mogą efektywnie zaspokajać potrzebę samorozwoju, gdy intencjonalnie poszerzają wiedzę, przejawiają własną ekspresję w domenie sztuki czy też w innej działalności kreatywnej. Do celu, jakim jest wzbogacenie i rozwój osobowości, droga prowadzi przez uprawianie zainteresowań i zamiłowan, przez aktywność społeczną i aktualizację dążeń samourzeczywistnienia.

Jednakże osobowość nie wyczerpuje całego bogactwa i złożoności struktury osoby, która posiada przede wszystkim swoją duchowość. Rozwój duchowości wymaga szczególnie ukierunkowanych subtelnych zabiegów doskonalących, które związane są z modlitwą, kontemplacją i autentycznym uczestnictwem w życiu Kościoła (sakramenty święte, ruch pielgrzymkowy, oazy rodzin, rekolekcje i inne). Zaniedbania w tej dziedzinie pracy nad sobą są nie tylko bolesne w skutkach dla podmiotów owych zaniedbań, czyli dla samych rodziców, ale także rzutują negatywnie na rozwój osobowy dziecka.

Społeczne formy aktywności samowychowawczej to również dobrowolne i bezinteresowne tworzenie i zrzeszanie się w kręgach i stowarzyszeniach o charakterze stricte samokształceniowym i samowychowawczym. Siłą motoryczną i wielkim wsparciem rodziców w ich pracy nad sobą może okazać się wspólne z dorastającym dzieckiem uczestnictwo w działalności jakieś grupy o wyraźnym modelu samokształceniowym i samowychowawczym. Stowarzyszenia, kluby i inne zespoły o takim charakterze mogą jednoczyć ludzi wokół wspólnych idei i wartości, spraw i problemów natury społecznej, politycznej i światopoglądowej. Biorąc udział w spotkaniach, odczytach, zbiorowych dyskusjach, a przede wszystkim włączając się w nurt społecznie i moralnie wartościowego działania, osoba ma szansę przezwyciężyć własne ograniczenia, słabości charakteru, rozwijać się intelektualnie, społecznie i duchowo. A wszystko to po to, by lepiej rozumieć świat i ludzi oraz pełniej uczestniczyć w doskonaleniu życia zbiorowego i jego ewangelizacji.

Zarysowane powyżej możliwości pracy rodziców nad sobą i przez nich racjonalnie wykorzystane prowadzą w efekcie do zdobycia, w sposób niemalże naturalny, umiejętności kierowania samowychowaniem dziecka, zwłaszcza w tych sytuacjach, w których wychowanie jest już mało skuteczne. Przedstawione propozycje nie stanowią jakiejś reguły czy ogólnych prawidłowości, których trzeba przestrzegać, mogą być one zignorowane i zmarnowane, jak wiele innych okazji w życiu człowieka, lecz zawsze mają szansę być podjęte i twórczo wykorzystane, i to za sprawą czy z inspiracji własnego

11 A. Gurycka, Zainteresowania dzieci i młodzieży, ich kształcenie i rozwój, w: L. Wołoszynowa (red.), Materiały do nauczania psychologii, seria II, t. 4, Warszawa 1969, s. 278, 282. 
dziecka - wspaniałej osoby, daru, który jest nam zadany wedle słów Ewangelii: Jeśli się nie staniecie jako dzieci, nie wnijdziecie do Królestwa niebieskiego (Mt 18, 3).

\section{Child as a Person and Inspiration for Parents' Self-Development (Summary)}

The discussion concerning family upbringing the most often takes into account only those inquiries which are related to the impacts of parents in relation to a child, and it avoids the wide possibilities of feedback interactions when a child becomes an inspiration for parents to improve themselves. This article presents the available areas of activity which parents can use in their pursue to self-improvement. The motive for such actions is not only parents' concern of the welfare of a child, but also the desire for self-development. Both motives should be harmonized, and never divergent.

Keywords: Christian family, natural upbringing, self-development, self-education

\section{Dziecko jako osoba i inspiracja samowychowania rodziców (Streszczenie)}

W rozważaniach o wychowaniu w rodzinie najczęściej uwzględnia się jedynie te dociekania, które odnoszą się do oddziaływań rodziców względem dziecka, natomiast pomija się szerokie możliwości oddziaływań zwrotnych, gdy osoba dziecka staje się inspiracją dla rodziców do pracy nad sobą. Artykuł ukazuje w tym drugim zakresie pewne potencjalnie istniejące obszary aktywności do zagospodarowania przez rodziców. Motywem podjęcia takich działan jest nie tylko troska rodziców o dobro dziecka, lecz także pragnienie własnego rozwoju. Oba motywy powinny być z sobą zharmonizowane, a nigdy rozbieżne.

Słowa kluczowe: rodzina chrześcijańska, naturalne wychowanie, samowychowanie, samokształcenie 
